Syntax Literate: Jurnal Ilmiah Indonesia p-ISSN: 2541-0849

e-ISSN : 2548-1398

Vol. 6, No. 10, Oktober 2021

\title{
PENGARUH TINGKAT PERTUMBUHAN, STRUKTUR MODAL, UKURAN PERUSAHAAN DAN UMUR PERUSAHAAN TERHADAP PROFITABILITAS PERUSAHAAN PERTAMBANGAN
}

\author{
Adrian Hartanto, Camila, Ike Rukmana Sari
}

Fakultas Ekonomi Universitas Prima Jakarta, Indonesia

Email: Adrian.hartanto7878@gmail.com, Camilalim14@gmail.com

Ikerukmana@gmail.com

\begin{abstract}
Abstrak
Perusahaan pertambangan membutuhkan modal yang sangat besar dalam mengeksplorasi sumber daya alam dalam mengembangkan pertambangan. Dalam penelitian ini peneliti tertarik untuk menjadikan sektor pertambangan sebagai objek penelitian karena sektor pertambangan mempunyai pengaruh yang sangat besar terhadap perekonomian Indonesia. Terlebih Indonesia merupakan negara penghasil sumber daya alam yang berpotensial sehingga dapat dimanfaatkan untuk meningkatkan pendapatan nasional. Penelitian ini menggunakan penelitian kuantitatif. Populasi pada penelitian ini adalah 30 perusahaan pertambangan sektor industri batu bara, besi dan mineral yang terdaftar di Bursa Efek Indonesia periode 2016- 2019. Teknik pengambilan sampel dilakukan dengan metode purposive sampling. Dengan jumlah sampel sebanyak 15 perusahan. Hasil akhir dari penelitian ini adalah struktur modal dan umur perusahaan tidak berpengaruh terhadap profitabilitas pada perusahaan pertambangan di Bursa Efek Indonesia periode 2016-2019. Tingkat pertumbuhan berpengaruh terhadap profitabilitas pada perusahaan pertambangan di Bursa Efek Indonesia periode 2016-2019. Ukuran perusahaan berpengaruh negatif dan signifikan terhadap profitabilitas pada perusahaan pertambangan di Bursa Efek Indonesia periode 2016-2019. Tingkat Pertumbuhan, Struktur Modal, Ukuran Perusahaan dan Umur Perusahaan secara simultan dan signifikan berpengaruh terhadap profitabilitas pada perusahaan pertambangan periode tahun 2016-2019. Untuk itu, perusahaan pertambangan banyak masuk ke pasar modal untuk menyerap investasi dan untuk memperkuat posisi keuangan.
\end{abstract}

Kata Kunci: tingkat pertumbuhan; struktur modal; ukuran perusahaan; umur perusahaan; profitabilitas

\section{Abstract}

Mining companies require enormous capital in exploring natural resources in developing mining. In this study, researchers are interested in making the mining sector the object of research because the mining sector has a very large influence on the Indonesian economy. Moreover, Indonesian is a potential natural resourceproducing country so that it can be used to increase national income. This research uses quantitative research. The population in this study was 30 mining companies Perusahaan Dan Umur Perusahaan Terhadap Profitabilitas Perusahaan Pertambangan. Syntax Literate: 
in the coal, iron and mineral industry sector listed on the Indonesia Stock Exchange for the period 2016-2019. Sampling techniques are performed by purposive sampling method. With a sample number of 15 companies. The final result of this study is that the capital structure and age of the company have no effect on profitability in mining companies on the Indonesia Stock Exchange for the period 2016-2019. The growth rate affects profitability in mining companies on the Indonesia Stock Exchange for the period 2016-2019. The size of the company negatively and significantly affects profitability in mining companies on the Indonesia Stock Exchange for the period 2016-2019. Growth Rate, Capital Structure, Company Size and Company Age simultaneously and significantly affect profitability in mining companies in the period 2016-2019. To that end, many mining companies go into the capital market to absorb investment and to strengthen the financial position.

Keywords: growth rate; capital structure; company size; company age; profitability

Received: 2021-09-20; Accepted: 2021-10-05; Published: 2021-10-20

\section{Pendahuluan}

Perusahaan pertambangan merupakan salah satu perusahaan penopang pembangunan ekonomi suatu negara karena perannya sebagai penyedia sumber daya energi yang sangat diperlukan bagi pertumbuhan perekonomian suatu negara (Fardiansyah, Siagian, \& Sihombing, 2018). Potensi yang kaya akan sumber daya alam akan dapat menumbuhkan terbukanya perusahaani-perusahaan untuk melakukan eksplorasi pertambangan sumber daya tersebuti (Sudrajat, 2018). Perusahaan pertambangan membutuhkan modal yang sangat besar dalam mengeksplorasi sumber daya alam dalam mengembangkan pertambangan. Untuk itui, perusahaan pertambangan banyak masuk ke pasar modal untuk menyerap investasi dan untuk memperkuat posisikeuangannya (Hayati, 2019).

Posisi keuangan dapat di lihat dari laporan keuangan, dimana laopran keuangan sangat penting bagi perusahaan untuk memperoleh berbagai informasi dalam segala hal. Secara sederhana menurut Secara sederhana Menurut (Prihadi, 2019) laporan keuangan adalah laporan yang menunjukkan kondisi keuangan perusahaan pada saat ini atau dalam suatu periode tertetu.

Pada dasarnya tujuan utama didirikan perusahaan adalah untuk mendapatkan profit (laba) dan sebagai lembaga usaha yang bekerja untuk mendapatkan kepercayaan konsumeni, sehingga perusahaan mampu beroperasi dan menghasilkan keuntungan secara terus-menerus sehingga kegiatan usaha tidak terhenti pada satu waktu tertentu saja (Umar, 2002).

Profitabilitas merupakan salah satu rasio yang dapat mengukur kemampuan perusahaan dalam menghasilkan laba dari aktiva yang digunakani (Sanjaya \& Rizky, 2018). Salah satu cara yang dapat dilakukan untuk mengukur kemampuan perusahaan adalah dengan melalukan analisis rasio keuangan (Gustina \& Wijayanto, 2015). Secara garis besar ada 5 jenis rasio yang dapat digunakan untuk menilai kinerja keuangan 
perusahaani, yaitu : rasio tingkat pertumbuhani, rasio struktur modali, rasio ukuran perusahaan, rasio umur perusahaan dan rasioprofitabilitas (Orniati, 2009).

Dalam menghasilkan profitabilitas pertumbuhan perusahaan sangat berpengaruh besar, sehingga pertumbuhan diharapkan dapat memberikan aspek positif bagi perusahaan agar meningktkan kesempatan berinvestasi diperusahaan tersebut. Perusahaan yang pertumbuhannya baik akan menghasilkan profitabilitas yang tinggi (Adyani \& Sampurno, 2011).

Tinggi rendahnya struktur modal sangat berpengaruh terhadap profitabilitas. Rasio ini menggambarkan kemampuan perusahaan dalam menggunakan hutang yang lebih banyak, berarti menggunakan modal yang lebih murah biaya modal hutang lebih kecil dibandingkan dengan biaya modal saham, sehingga akan menurunkan biaya modal ratarata tertimbangnya meski biaya modal saham meningkat. Karena semakin tinggi tingkat hutang suatu perusahaan, akan semakin tinggi juga kemungkinan kebangkrutannya. Perusahaan yang mampu mengatur hutangnya akan meningkatkan profitabilitas perusahaan (Christiawan \& Tarigan, 2007).

Ukuran perusahaan sangat berpengaruh terhadap profitabiitas, karena rasio ini menjelaskan kemampuan perusahaan dalam mengolah asetnya,jika nilai rasio ini tinggi berarti seluruh aset digunakan dengan baik untuk menunjang aktivitas penjualan guna memperoleh laba (Indriyani, 2017). Kondisi ini menerangkan bahwa adanya pengaruh positif total aset terhadap profitabilitasi

Umur Perusahaan merupakan rasio yang menggambarkan berapa lama suatu perusahaan berdiri. Umur perusahaan juga menjadi bahan pertimbangan investor dalam menanamkan modalnya, umur perusahaan mencerminkan perusahaan tetap survive dan menjadi bukti bahwa mampu bersaing dan dapat mengambil kesempatan bisnis yang ada dalam perekonomiani. Perusahaan yang telah lama berdiri umumnya memiliki profitabilitas yang lebih stabil dan perusahaan yang lama berdiri akan meningkatkan laba karena adanya pengalaman dari manajemen sebelumnya dalam mengelola bisnis (Indriyani, 2017).

Tabel 1

Fenomena Penelitian Periode 2017-2019

\begin{tabular}{|c|c|c|c|c|c|}
\hline $\begin{array}{c}\text { Kode } \\
\text { Emiten }\end{array}$ & $\begin{array}{c}\text { Tahu } \\
\text { n }\end{array}$ & Total Aset & Total Utang & $\begin{array}{c}\text { Umur } \\
\text { Perusahaa } \\
n\end{array}$ & Laba Bersih \\
\hline \multirow[t]{3}{*}{ Byan } & 2017 & $888,813,140$ & $\begin{array}{l}373,209,3 \\
21\end{array}$ & 19 Thn & $\begin{array}{l}338,017,1 \\
99\end{array}$ \\
\hline & 2018 & $\begin{array}{l}1,150,863,8 \\
91\end{array}$ & $\begin{array}{l}472,793,5 \\
57\end{array}$ & 20 Thn & $\begin{array}{l}524,309,2 \\
73\end{array}$ \\
\hline & 2019 & $\begin{array}{l}1,278,040,1 \\
23\end{array}$ & $\begin{array}{l}658,959,9 \\
60\end{array}$ & 21 Thn & $\begin{array}{l}234,211,2 \\
77\end{array}$ \\
\hline \multirow[t]{3}{*}{ Ptba } & 2017 & $21,987,482$ & $\begin{array}{l}8,187,4 \\
97\end{array}$ & 36 Thn & $\begin{array}{l}4,547, \\
232\end{array}$ \\
\hline & 2018 & $\begin{array}{l}24,172,9 \\
33\end{array}$ & $\begin{array}{l}7,903,2 \\
37\end{array}$ & $\begin{array}{l}37 \\
\text { Thn }\end{array}$ & $\begin{array}{l}5,121,1 \\
12\end{array}$ \\
\hline & 2019 & $26,098,0$ & $7,675,2$ & 38 & $4,040,3$ \\
\hline
\end{tabular}




\begin{tabular}{|c|c|c|c|c|c|}
\hline & & 52 & 26 & Thn & 94 \\
\hline \multirow[t]{3}{*}{ Hrum } & 2017 & $459,443,071$ & $\begin{array}{l}63,582,3 \\
49\end{array}$ & 22 Thn & $\begin{array}{l}55,748,0 \\
01\end{array}$ \\
\hline & 2018 & $467,989,195$ & $\begin{array}{l}\text { 79,502,4 } \\
04\end{array}$ & 23 Thn & $\begin{array}{l}40,205,4 \\
22\end{array}$ \\
\hline & 2019 & $447,001,954$ & $\begin{array}{l}47,418,4 \\
41\end{array}$ & 24 Thn & $\begin{array}{l}20,122,5 \\
89\end{array}$ \\
\hline
\end{tabular}

Berdasarkan tabel 1 menunjukkan bahwa tingkat pertumbuhan yang diproksikan dengan total asset tahun 2019 mengalami peningkatan dari tahun 2018 sebesar Rp127.176.232 pada PT. Bayan Resource Tbk (BYAN) sedangkan profitabilitas yang diproksikan dengan laba bersih tahun 2019 mengalami penurunan dari tahun 2018 sebesar Rp290.097.996.

Struktur Modal yang diproksikan dengan total liabilities tahun 2019 mengalami penurunan dari tahun 2018 sebesar Rp 32.083.963 pada PT. Harum Energy Tbk (HRUM) sedangkan profitabilitas yang diproksikan dengan laba berish tahun 2019 mengalami penurunan dari tahun 2018 sebesar Rp 20.082.833.

Ukuran Perusahaan yang diproksikan dengan total asset tahun 2019 mengalami peningkatan dari tahun 2018 sebesar Rp 1.925.119 pada PT. Bukit Asam Tbk (PTBA) sedangkan profitabilitas yang diproksikan dengan laba bersih tahun 2019 mengalami penurunan dari tahun 2018 sebesar Rp 1.080.718.

Umur Perusahaan yang dilihat dari lama berdirinya pada tahun 2019 umur perusahan PT. Bukit Asma Tbk (PTBA) adalah 38 tahun dengan laba bersih pada tahun tersebut sebesar Rp 4.040.394 sedangkan pada tahun 2018 PT. Bukit Asma Tbk (PTBAi) berumur 37 tahun dengan laba bersih pada tahun tersebut sebesar Rp 5.121.112.

Berdasarkan latar belakang diatas, peneliti tertarik untuk mengambil judul "Pengaruh Tingkat pertumbuhani, Strukrut modal, Ukuran Perusahaan dan Umur Perusahaan terhadap Profitabilitas Perusahaan Pertambangan yang terdaftar di Bursa Efek Indonesia (BEI) periode 2016-2019”.

\section{Metode Penelitian}

Jenis penelitian ini menggunakan pendekatan kuantitatif (Cresswell, 2017) data yang digunakan adalah data yang bersifat kuantitatif karena dinyatakan dengan angkaiangka yang menunjukkan nilai terhadap besaran atas variabel yang diwakilinya. Sumber data yang digunakan adalah data sekunder. Jenis penelitian yang digunakan adalah penelitian deskriptif.

Menurut (Sugiyono, 2017) sampel adalah bagian dari jumlah dan karakteristik yang dimiliki oleh populasi tersebut. Teknik pengambilan sampel dilakukan dengan metode purposive sampling. Pengambilan sampel penelitian dengan melakukan kriteria yang di tetapkan sebagai berikut :

1. Perusahaani pertambangan sector industry batubara, besi dan mineral yang terdaftar di BEI yang berturut-turut selama periode 2016-2019. 
2. Perusahaan pertambangan sektor batubara, besi dan mineral yang mempublikasikan laporan keuangan di (BEI) periode 2016-2019

3. Perusahaan pertambangan yang memperoleh laba periode 2016-2019.

\section{Tabel 2}

\section{Pengambilan Sampel Penelitian}

\begin{tabular}{llc}
\hline No. & \multicolumn{1}{c}{ Kriteria } & Jumlah \\
\hline 1 & $\begin{array}{l}\text { Perusahaan pertambangan sector industry batubara, besi dan mineral yang } \\
\text { terdaftar di BEI periode 2016 -2019 }\end{array}$ & 30 \\
\hline 2 & $\begin{array}{l}\text { Perusahaan pertambangan sector batubara, besi dan mineral yang tidak rutin } \\
\text { mempublikasikan laporan keuangan di (BEI ) periode 2016-2019 }\end{array}$ & $(4)$ \\
\hline 3 & Perusahaan pertambangan yang mengalami kerugian periode 2016-2019 & $(11)$ \\
\hline Jumlah perusahaan yang memenuhi criteria sampel & 15 \\
\hline Total sampel selama periode berjalan ( 15x4 tahun ) & 60 \\
\hline
\end{tabular}

Penelitian ini menggunakan jenis data sekunder dengan teknik pengambilan data melalui metode dokumentasi. Metode Dokumentasi pada penelitian ini diperoleh dari data laporan keuangan tahunan perusahaan sektor pertambangan yang terdaftar di Bursa Efek Indonesia www. idx. co. idi/ periode dari tahun 2016-2019.

\section{Hasil dan Pembahasan}

\section{A. Hasil Penelitian}

1. Uji Statistik Deskriptif

Dalam penelitian ini, peneliti menggunakan statistik deskriptif (Nasution, 2017). Berikut adalah data statistik secara umum dari variabel yang digunakan dalam penelitian ini.

Tabel 3

Statistik Deskriptif

Descriptive Statistics

\begin{tabular}{lrrrrr}
\hline & $\mathrm{N}$ & $\begin{array}{l}\text { Minimu } \\
\mathrm{m}\end{array}$ & $\begin{array}{l}\text { Maximu } \\
\mathrm{m}\end{array}$ & Mean & $\begin{array}{l}\text { Std. } \\
\text { Deviation }\end{array}$ \\
\hline $\mathrm{X} 1$ & 60 & -.2999160 & .5634532 & .078867569 & .1625507614 \\
\hline $\mathrm{X} 2$ & 60 & -15.8173077 & 24.2985282 & 1.062988110 & 5.3011682088 \\
\hline $\mathrm{X} 3$ & 60 & 14.0053380 & 22.0859778 & 19.359984187 & 2.0331469323 \\
\hline $\mathrm{X} 4$ & 60 & 9 & 46 & 23.37 & 8.692 \\
\hline $\mathrm{Y}$ & 60 & -.4159364 & .3941084 & .077091551 & .1206427189 \\
\hline $\begin{array}{l}\text { Valid N } \\
\text { (listwise) }\end{array}$ & 60 & & & & \\
\hline
\end{tabular}

Untuk variabel Tingkat Pertumbuhan (X1) nilai minimum sebesar 0,2999160 dan nilai maksimum sebesar 0,5634532 sedangkan nilai ratai-rata sebesar 0,078867569 dengan standar deviasi sebesar 0, 1625507614 dengan sampel sebanyak 60 perusahaani.

Untuk variabel Struktur Modal (X2) nilai minimum sebesar -15, 8173077 dan nilai maksimum sebesar 24, 2985282 sedangkan nilai ratai-rata sebesar 1, 
062988110 dengan standar deviasi sebesar 5, 3011682088 dengan sampel sebanyak 60 perusahaan.

Untuk variabel Ukuran Perusahaan (X3) nilai minimum sebesar 14, 0053380 dan nilai maksimum sebesar 22,0859778 sedangakan nilai ratai-rata sebesar 19, 359984187 dengan standar deviasi sebesar 2, 0331469323 dengan sampel sebanyak 60 perusahaani.

Untuk variabel Umur Perusahaan (X4) nilai minimum sebesar 9 dan nilai maksimum sebesar 46 sedangkan nilai ratai-rata sebesar 23, 37 dengan standar deviasi sebesar 0,1206427189 dengan sampel sebanyak 60 perusahaani.

Untuk variabel Profitabilitas (Y) nilai minimum sebesar -0, 4159364 dan nilai maksimum sebesar 0,3941084 sedangkan nilai ratai-rata sebesar 0 , 077091551 dengan standar deviasi 0, 1206427189 dengan sampel sebanyak 60 perusahaan.

2. Hasil Uji Asumsi Klasik

a. Uji Normalitas

Tabel 4

Uji Statistik Kolmogorov-Smirnov One-Sample Kolmogorov-Smirnov Test

\begin{tabular}{llr}
\hline & & $\begin{array}{r}\text { Unstandardize } \\
\text { dResidual }\end{array}$ \\
\hline $\mathrm{N}$ & Mean & 60 \\
\hline Normal Parameters & a,b-7 \\
& Std. Deviation & .09535171 \\
\hline & Absolute & .118 \\
\hline Most Extreme & Positive & .118 \\
Differences & & -.091 \\
\hline \multicolumn{2}{l}{ Negative } \\
\hline Kolmogorov-Smirnov Z & .915 \\
\hline Asymp. Sig. (2-tailed) & .373 \\
\hline $\begin{array}{l}\text { a. Test Distribution is Normal } \\
\text { b. Calculated from Data }\end{array}$
\end{tabular}

Berdasarkan tabel 4 Kolmogorov maka dapat disimpulkan bahwa hasil uji normalitas dengan menggunakan metode One-Sample Kolmogorov-Smirnov test menunjukkan tidak terjadi penyimpangan atau data berdistribusi normal. Hal ini ditunjukkan dari nilai signifikansi 0, 373 yang hasilnya lebih besar dari taraf signifikansi 0,05 . 


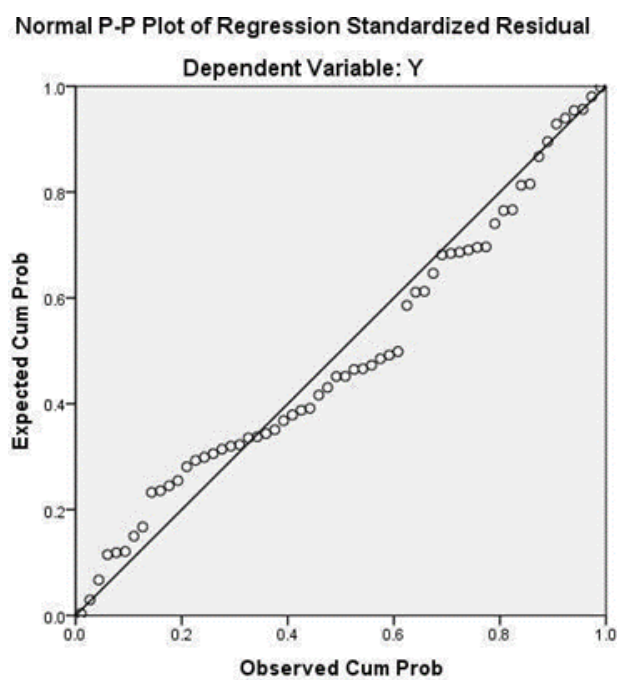

Gambar 1

Grafik Normality Probability Plot

Pada gambar 1 diatas (Normality Probability Plot), dapat dilihat bahwa gambar titik-titik pada P-Plot terlihat mengikuti dan mendekati garis diagonalnya sehingga dapat disimpulkan bahwa data telat berdistribusi normal.

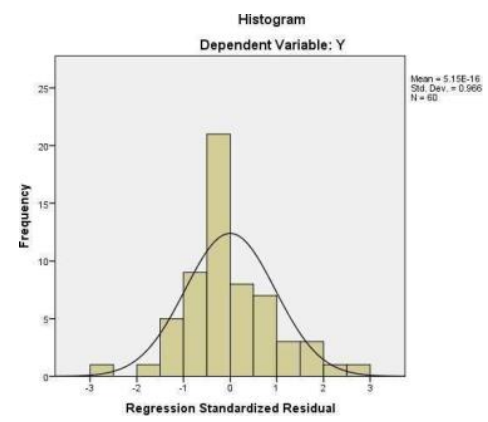

Gambar 2

\section{Grafik Histogram Regression Standardized Residual}

Dari hasil grafik histogram (Normal P-P Plot of Regression Standardized Residual) memperlihatkan bahwa kurva (garis kurva condong simetri U) yang dapat simpulkan bahwa data berdistribusi normal.

b. Uji Multikolinearitas

Tabel 5

Coefficientsa

\begin{tabular}{|c|c|c|c|c|c|c|c|}
\hline \multirow[t]{2}{*}{ Model } & \multicolumn{2}{|c|}{$\begin{array}{l}\text { Unstandardized } \\
\text { Coefficients }\end{array}$} & $\begin{array}{c}\text { Standadized } \\
\text { Coefficients }\end{array}$ & \multirow[t]{2}{*}{$\mathrm{t}$} & \multirow[t]{2}{*}{$\begin{array}{l}\mathrm{Si} \\
\text { g. }\end{array}$} & \multicolumn{2}{|c|}{$\begin{array}{l}\text { Collinearity } \\
\text { Statistics }\end{array}$} \\
\hline & B & $\begin{array}{l}\text { Std. } \\
\text { Error }\end{array}$ & Beta & & & $\begin{array}{l}\text { Toleran } \\
\text { ce }\end{array}$ & VIF \\
\hline (Constant) & .459 & .124 & & 3.691 & .001 & & \\
\hline $\mathrm{X} 1$ & .368 & .084 & .496 & 4.363 & .000 & .879 & 138 \\
\hline $1 \mathrm{X} 2$ & .003 & .003 & .129 & 1.104 & .274 & .836 & 196 \\
\hline
\end{tabular}




\begin{tabular}{llllllll}
\hline $\mathrm{X} 3$ & -.022 & .007 & -.377 & -3.426 & .001 & .937 & 1.067 \\
\hline $\mathrm{X} 4$ & .001 & .002 & .059 & .512 & .610 & .848 & 1.179 \\
\hline
\end{tabular}

a. Dependent Variabel Y

Uji Multikolinearitas bertujuan untuk menguji apakah suatu model regresi terdapat korelasi antara variabel bebas (independen). Untuk mendeteksi ada tidaknya multikolinearitasi dapat dilihat dari besaran variance inflation factor (VIF) dan Tolerance. Pengujian Multikolinearitas dapat dilakukan sebagai berikut

1) Tolerance value $<0,10$ atau VIF $>10$ : terjadi multikolinearitas.

2) Tolerance value $>0,10$ atau VIF $<10$ : tidak terjadi multikolinearitas.

Berdasarkan hasil uji multikolinearitas pada tabel diatas menunjukkan bahwa nilai Tolerance variabel Tingkat Pertumbuhani, Struktur Modal, Ukuran Perusahaan dan Umur Perusahaan > 0, 10 sedangkan nilai VIF variabel Tingkat Pertumbuhani, Struktur Modal, Ukuran Perusahaan dan Umur Perusahaan < 10, maka dapat dikatakan tidak terjadi multikolinearitasi.

c. Uji Autokorelasi

Uji autokorelasi bertujuan untuk mengetahui ada atau tidaknya penyimpangan asumsi klasik autokorelasii, yaitu korelasi yang terjadi pada satu pengamatan dengan pengamatan yang lain pada model regresi. Untuk mendeteksi ada tidaknya autokorelasi digunakan uji Durbin Watson.

\section{Tabel 6}

Model Summary

\begin{tabular}{llrrrr}
\hline Model & $\mathrm{R}$ & R Square & $\begin{array}{c}\text { Adjusted } \\
\mathrm{R} \\
\text { Square }\end{array}$ & $\begin{array}{l}\text { Std. Error of } \\
\text { the } \\
\text { Estimate }\end{array}$ & Durbin-Watson \\
\hline 1 & $.613^{\mathrm{a}}$ & .375 & .330 & $\begin{array}{l}.098758197 \\
4\end{array}$ & 1.571 \\
\hline
\end{tabular}

a. Predictors: (Constant), X4, X1, X3, X2

b. Dependent Variable: Y

Berdasarkan hasil uji Autokorelasi pada tabel diatas diketahui bahwa nilai Durbin- Watson $(\mathrm{DW})=1,571$, dengan " $\mathrm{k}$ " $=4$ dengan jumlah sampel 60 sehingga didapat nilai $\mathrm{dL}$ (batas bawah) $=1,4443$ dan $\mathrm{dU}$ (batas atas) $=1$, 7274. Maka nilai $\mathrm{dL}<\mathrm{dw}<\mathrm{du}$ atau $1,4443<1,571<1,7274$ maka dapat disimpulkan bahwa tidak terjadi autokorelasi.

d. Uji Heteroskedastisitas 
Uji Heteroskedastisitas yaitu untuk menguji apakah dalam model regresi terjadi ketidaksamaan dari residual satu pengamatan yang lain

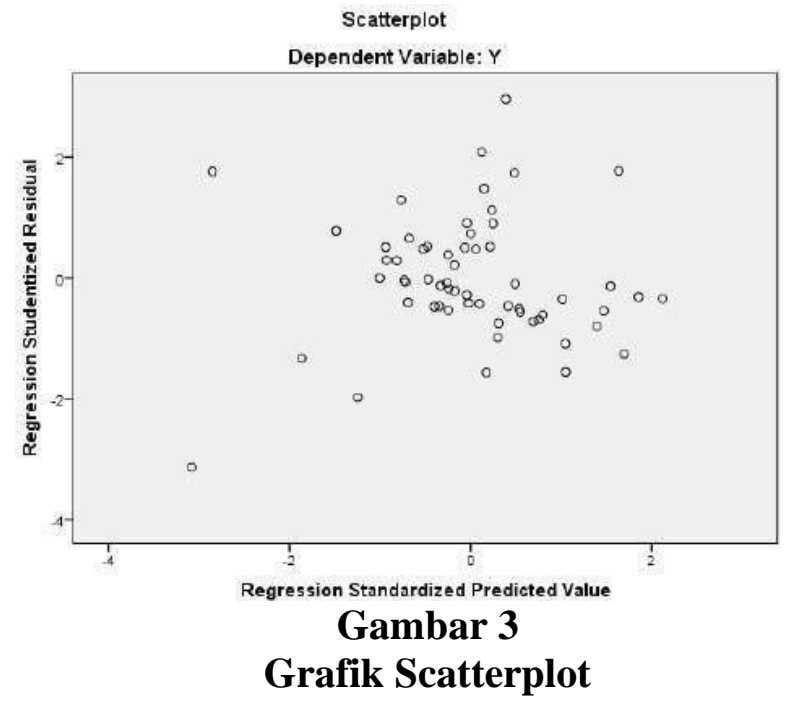

Dilihat dari grafik scatterplot diatas bahwa titik-titik yang menyebar atau berpencar secara acak serta tidak berkumpul pada satu tempat, jadi dapat disimpulkan bahwa tidak terjadi heteroskedastisitas.

Tabel 7

Uji Glejser

Coefficientsa

\begin{tabular}{|c|c|c|c|c|c|c|}
\hline \multirow{2}{*}{\multicolumn{2}{|c|}{ Model }} & \multicolumn{2}{|c|}{ Unstandardized Coefficients } & \multirow{2}{*}{$\begin{array}{c}\begin{array}{c}\text { Standardized } \\
\text { Coefficients }\end{array} \\
\text { Beta }\end{array}$} & \multirow[t]{2}{*}{$\mathrm{t}$} & \multirow[t]{2}{*}{$\mathrm{Si}$} \\
\hline & & B & Std. Error & & & \\
\hline & $\begin{array}{l}\text { (Const } \\
\text { ant) }\end{array}$ & -2.283 & 2.751 & & -.830 & .410 \\
\hline & $\begin{array}{l}\mathrm{X} \\
1\end{array}$ & 1.589 & 1.867 & .109 & .851 & .398 \\
\hline 1 & $\mathrm{X} 2$ & -.130 & .059 & -.292 & -2.223 & .030 \\
\hline & $\begin{array}{l}X \\
3\end{array}$ & -.124 & .145 & -.107 & -.858 & .395 \\
\hline & $\begin{array}{l}X \\
4\end{array}$ & -.064 & .036 & -.234 & -1.789 & .079 \\
\hline
\end{tabular}

a. Dependent Variable: lnres

Hasil uji glejser pada tabel 7 diatas menunjukkan nilai sig untuk variabel tingkat pertumbuhani, struktur modali, ukuran perusahaan dan umur perusahaan memiliki nilai signifikansi lebih besar dari 0, 05 sehingga dapat dikatakan tidak tejadi masalah heteroskedastisitas.

3. Hasil Analisis Data Penelitian

a. Uji Regresi Linear Berganda 


\section{Tabel 8}

\section{Coefficients $^{\mathrm{a}}$}

\begin{tabular}{|c|c|c|c|c|c|c|}
\hline \multirow{2}{*}{\multicolumn{2}{|c|}{ Model }} & \multicolumn{2}{|c|}{$\begin{array}{l}\text { Unstandardized } \\
\text { Coefficients }\end{array}$} & \multirow{2}{*}{$\begin{array}{c}\begin{array}{r}\text { Standardized } \\
\text { Coefficients }\end{array} \\
\text { Beta }\end{array}$} & \multirow[t]{2}{*}{$\mathrm{t}$} & \multirow[t]{2}{*}{$\begin{array}{l}\mathrm{Si} \\
\text { g. }\end{array}$} \\
\hline & & B & $\begin{array}{l}\text { Std. } \\
\text { Error }\end{array}$ & & & \\
\hline & (Constant) & .459 & .124 & & 3.691 & .001 \\
\hline & $\begin{array}{c}\mathrm{X} \\
1\end{array}$ & .368 & .084 & .496 & 4.363 & .000 \\
\hline 1 & $\mathrm{X} 2$ & .003 & .003 & .129 & 1.104 & .274 \\
\hline & $\begin{array}{l}X \\
3\end{array}$ & -.022 & .007 & -.377 & -3.426 & .001 \\
\hline & $\begin{array}{c}X \\
4\end{array}$ & .001 & .002 & .059 & .512 & .610 \\
\hline
\end{tabular}

a. Dependent Variabel Y

Berdasarkani Tabel 8 diperoleh model persamaan regresi linear berganda sebagai berikut :

$$
\begin{aligned}
& Y=a+b 1 \times 1+b 2 \times 2+b 3 \times 3+b 4 \times 4+e \\
& Y=0,459+0,368 X 1+0,003 \times 2+(-0,022) X 3+0,001 X 4+e
\end{aligned}
$$

Penjelasan dari persamaan tersebut adalah sebagai berikut:

1) Nilai konstanta a sebesar 0i, 459 yang artinya variabel Tingkat pertumbuhani, struktur modali, ukuran perusahaan dan umur perusahaan dianggap konstanta, maka profitabilitas pada perusahaan pertambangan yang terdaftar di Bursa Efek Indoneisa periode 2016-2019 akan mengalami peningkatan 0,459 .

2) Nilai koefisien tingkat pertumbuhan (X1) adalah 0, 368 yang menunjukkan setiap peningkatan tingkat pertumbuhan sebesar 1 satuan, maka nilai profitabilitas mengalami peningkatan sebesar 0,368.

3) Nilai koefisien struktur modal (X2) adalah 0, 003 yang menunjukkan setiap peningkatan struktur modal sebesar 1 satuani, maka nilai profitabilitas mengalami peningkatan sebesar 0,003.

4) Nilai koefisien ukuran perusahaan (X3) adalah -0, 022 yang menunjukkan setiap peningkatan ukuran perusahaan sebesar 1 satuani, maka nilai profitabilitas mengalami penurunan sebesar 0,022 .

5) Nilai koefisien umur perusahaan (X4) adalah 0, 001 yang menunjukkan setiap peningkatan umur perusahaan sebesar 1 satuan, maka nilai profitabilitas mengalami peningkatan sebesar 0,001 .

b. Uji Koefisien Determinasi 


\begin{tabular}{|c|c|c|c|c|}
\hline \multicolumn{5}{|c|}{$\begin{array}{c}\text { Tabel } 9 \\
\text { Koefisien Determinasi } \\
\text { Model Summarv }^{b}\end{array}$} \\
\hline Model & $\mathrm{R}$ & R Square & $\begin{array}{l}\text { Adjusted R } \\
\text { Square }\end{array}$ & $\begin{array}{l}\text { Std. Error of the } \\
\text { Estimate }\end{array}$ \\
\hline 1 & $.613^{\mathrm{a}}$ & .375 & .330 & .0987581974 \\
\hline
\end{tabular}

a. Predictors: (Constant), X4, X1, X3, X2

b. Dependent Variable: $\mathrm{Y}$

Berdasarkan hasil uji koefisien determinasi menunjukkan nilai Adjusted R Square sebesar 0, 330 atau 33\%. Dimana variabel dependen Profitabilitas yang dapat dijelaskan oleh variabel Tingkat Pertumbuhani, Struktur Modal, Ukuran Perusahaan dan Umur Perusahaan adalah sebesar 33\% sedangkan sisanya sebesar $67 \%$ dijelaskan oleh variabel lain yang tidak dibahas dalam penelitian ini.

c. Uji F (Secara Simultan)

Uji Statistik F digunakan untuk mengetahui apakah ada pengaruh secara bersamasama antara variabel-variabel independen terhadap variabel dependen.

Tabel 10

Pengujian Hipotesis Secara Simultan (Uji F)

ANOVA

\begin{tabular}{rlrrrrr}
\hline \multicolumn{1}{l}{ Model } & Sum of Squares & df & Mean Square & F & Sig. \\
\hline & Regression & .322 & 4 & .081 & 8.261 & $.000^{\mathrm{b}}$ \\
\hline 1 & Residual & .536 & 55 & .010 & & \\
\hline \multicolumn{2}{l}{ Total } & .859 & 59 & & & \\
\hline
\end{tabular}

a. Dependent Variable: Y

b. Predictors: (Constant), X4, X1, X3, X2

Berdasarkan hasil uji Anova atau F test pada tabel IIIi. 7, diperoleh nilai Fhitung 8,261 dengan Ftabel 2, 54 dan nilai signifikansinya sebesar 0, $000<0$, 05. Maka Fhitung 8,261 > Ftabel 2, 54 sehingga Ho ditolak dan Ha diterima sehinga variabel tingkat pertumbuhani, struktur modal, ukuran perusahaan dan umur perusahaan secara simultan dan signifikan berpengaruh terhadap profitabilitas pada perusahaan pertambangan periode tahun 2016-2019.

d. Uji T (Secara Parsialial)

Uji t digunakan untuk menunjukkan seberapa jauh pengaruh satu variabel independen secara individual dalam menerangkan variabel dependen 
Tabel 11

Pengujian Hipotesis Secara Parsial (Uji T)

Coefficients $^{\mathbf{a}}$

\begin{tabular}{|c|c|c|c|c|c|}
\hline \multirow[t]{2}{*}{ Model } & \multicolumn{2}{|c|}{$\begin{array}{c}\text { Unstandardized } \\
\text { Coefficients }\end{array}$} & \multirow{2}{*}{$\begin{array}{c}\text { Standardized } \\
\text { Coefficients } \\
\text { Beta } \\
\end{array}$} & \multirow[t]{2}{*}{$\mathrm{t}$} & \multirow[t]{2}{*}{ Sig. } \\
\hline & B & Std. Error & & & \\
\hline (Constant) & .459 & .124 & & 3.691 & .001 \\
\hline $\mathrm{X} 1$ & .368 & .084 & .496 & 4.363 & .000 \\
\hline $1 \mathrm{X} 2$ & .003 & .003 & .129 & 1.104 & .274 \\
\hline X3 & -.022 & .007 & -.377 & -3.426 & .001 \\
\hline $\mathrm{X} 4$ & .001 & .002 & .059 & .512 & .610 \\
\hline
\end{tabular}

a. Dependent Variable: Y

Hasil uji $\mathrm{T}$ pada tabel 11 diperoleh nilai Ttabel untuk probabilitas 0, 05 pada derajat bebas $\mathrm{df}=55$ yaitu sebesar 2, 00404. Demikian hasil uji $\mathrm{T}$ dijelaskan sebagai berikut:

1) Berdasarkan hasil uji t (secara parsial) variabel Tingkat Pertumbuhan (X1) mempunyai nilai Thitung sebesar 4, 363 sedangkan nilai Ttabel sebesar 2, 00404 maka Thitung > Ttabel $(4,363>2$, 00404) dengan nilai signifikansi $0,000<0,05$ yang artinya variabel tingkat pertumbuhan berpengaruh signifikan terhadap profitabilitas pada perusahaan pertambangan di Bursa Efek Indonesia periode 2016i-2019.

2) Berdasarkan hasil uji t (secara parsiali) variabel Struktur Modal (X2) mempunyai nilai Thitung sebesar 1,104 sedangkan nilai Ttabel sebesar 2, 00404 maka Thitung < Ttabel $(1,104<2,00404)$ dengan nilai signifikansi 0, $274>0,05$ yang artinya variabel struktur modal tidak berpengaruh signifikan terhadap profitabilitas pada perusahaan pertambangan di Bursa Efek Indonesia periode 2016i-2019.

3) Berdasarkan hasil uji t (secara parsial) variabel Ukuran Perusahaan (X3) mempunyai nilai Thitung sebesar $-3,426$ sedangkan nilai Ttabel sebesar 2,00404 maka -Thitung <-Ttabel $(-3,426<-2$, 00404) dengan nilai signifikasnsi $0,001<0$, 05 yang artinya variabel ukuran perusahaan berpengaruh negatif dan signifikan terhadap profitabilitas pada perusahaan pertambangan di Bursa Efek Indonesia periode 2016-2019.

4) Berdasarkan hasil uji t (secara parsial) variabel Umur Perusahaan (X4) mempunyai nilai Thitung sebesar 0,512 sedangkan nilai Ttabel sebesar 2, 00404 maka Thitung < Ttabel $(0,512<2,00404)$ dengan nilai signifikansi $0,610>0,05$ yang artinya variabel umur perusahaan tidak berpengaruh signifikan terhadap profitabilitas pada perusahaan pertambangan di Bursa Efek Indonesia periode 2016-2019. 
Pengaruh Tingkat Pertumbuhan, Struktur Modal, Ukuran Perusahaan dan Umur Perusahaan Terhadap Profitabilitas Perusahaan Pertambangan

\section{B. Pembahasan}

\section{Pengaruh Tingkat Pertumbuhan terhadap Profitabilitas}

Berdasarkan hasil pengujian hipotesis secara parsial (Uji t) diperoleh hasil bahwa tingkat pertumbuhan (X1) berpengaruh signifikan terhadap profitabilitas pada perusahaan pertambangan di Bursa Efek Indonesia periode 2016-2019 dengan nilai Thitung > Ttabel $(4,363>2,00404 i)$ dengan nilai signifikansi 0i, $000<0$, 05. Hasil dari penelitian ini menunjukkan bahwa jika pertumbuhan perusahaan suatu perusahaan mengalami peningkatan maka profitabilitasnya pun akan meningkati. Hasil penelitian ini sejalan dengan penelitian Nurhasanah (2014), Sari (2015) dan Lestiani (2016) yang menyatakan asset growth berpengaruh positif dan signifikan terhadap ROA.

\section{Pengaruh Struktur Modal terhadap Profitabilitas}

Berdasarkan hasil pengujian hipotesis secara parsial (Uji t) diperoleh hasil bahwa struktur modal (X2) tidak berpengaruh signifikan terhadap profitabilitas pada perusahaan pertambangan di Bursa Efek Indonesia periode 2016-2019 dengan nilai Thitung < Ttabel $(1,104<2$, 00404) dengan nilai signifikansi 0, $274>0$, 05. Hasil penelitian ini menunjukkan bahwa perusahaan yang mampu mengatur hutangnya ataupun tidak maka tiudak mempengaruhi peningkatkan profitabilitas perusahaan. Dimana hasil penelitian ini berbeda dengan teori yang diperoleh mengatakan memiliki hutang kecil tentunya memperbesar peluang untuk mendapatkan profitabilitas yang tinggi karena tingkat profitabilitas yang tinggi mempunyai sumber dana yang melimpah. Hasil penelitian ini selaras dengan penelitian (Iswanaji \& Rionita , 2018) yang menyatakan DER tidak berpengaruh signifikan terhadap ROAi. Namun berbeda dengan penelitian yang dilakukan oleh Wardana (2016) dan Pratiwi (2015) yang menyatakan bahwa DER berpengaruh signifikan terhadap ROA.

\section{Pengaruh Ukuran Perusahaan terhadap Profitabilitas}

Berdasarkan hasil pengujian hipotesis secara parsial (Uji t) diperoleh hasil bahwa ukuran perusahaan (X3) berpengaruh negatif dan signifikan terhadap profitabilitas pada perusahaan pertambangan di Bursa Efek Indonesia periode 2016-2019 dengan nilai -Thitung $<$ - Ttabel $(-3,426<-2$, 00404) dengan nilai signifikasnsi $0,001<0,05$. Hasil penelitian ini menunjukkan bahwa semakin besar ukuran perusahan maka semakin besar profitabilitas mendapatkan labai. Hasil penelitian ini sejalan dengan penelitian (Anindito \& HARTO, 2015) yang menyatakan bahwa ukuran perusahaan berpengaruh negatif dan signifikan terhadap profitabilitasi. Tetapi berbeda dengan penelitian yang dilakukan (Pangestuti, 2016) yang menyatakan bahwa ukuran perusahaan berpengaruh positif dan signifikan terhadap profitabilitasi.

\section{Pengaruh Umur Perusahaan terhadap Profitabilitasi}

Berdasarkan hasil pengujian hipotesis secara parsial (Uji t) diperoleh hasil bahwa umur perusahaan (X4i) tidak berpengaruh signifikan terhadap profitabilitas pada perusahaan pertambangan di Bursa Efek Indonesia periode 
2016-2019 dengan nilai Thitung $<$ Ttabel $(0,512<2$, 00404) dengan nilai signifikansi 0, $610>0$, 05. Hasil penelitian ini menunjukkan bahwa perusahaan yang sudah lama berdiri ataupun perusahaan baru tidak mempengaruhi profiitabilitas suatu perusahaani. Dimana hasil penelitian ini berbeda dengan teori yang diperoleh yaitu semakin lama umur sebuah perusahaan maka investor akan menanam modalnya diperusahaan yang telah lama berdiri dibandingkan perusahaan yang baru berdiri sehingga mempermudah menambah profitabilitas perusahaan. Hasil penelitian ini sejalan dengan (Sidabutar, 2020) yang menyatakan bahwa umur perusahaan tidak berpengaruh terhadap profitabilitas perusahaani. Tetapi berbeda denagn penelitian yang dilakukan (Mahalani, Iksan, Marisa Kurnianingsih, \& MH, 2016) yang menyatakan bahwa umur perusahaan berpengaruh positif dan signifikan terhadap profitabilitasi

\section{Kesimpulan}

Berdasarkan pada hasil penelitian, maka kesimpulan yang diperoleh dari penelitian ini adalah tingkat Pertumbuhan berpengaruh terhadap profitabilitas pada perusahaan pertambangan di Bursa Efek Indonesia periode 2016-2019. Struktur Modal tidak berpengaruh terhadap profitabilitas pada perusahaan pertambangan di Bursa Efek Indonesia periode 2016-2019. Ukuran Perusahaan berpengaruh negatif dan signifikan terhadap profitabilitas pada perusahaan pertambangan di Bursa Efek Indonesia periode 2016-2019. Umur Perusahaan tidak berpengaruh terhadap profitabilitas pada perusahaan pertambangan di Bursa Efek Indonesia periode 2016-2019. Tingkat Pertumbuhani, Struktur Modal, Ukuran Perusahaan dan Umur Perusahaan secara simultan dan signifikan berpengaruh terhadap profitabilitas pada perusahaan pertambangan periode tahun 2016-2019. 


\section{BIBLIOGRAFI}

Adyani, Lyla Rahma, \& Sampurno, D. R. D. (2011). Analisis faktor-faktor yang mempengaruhi profitabilitas (ROA). Jurnal Dinamika Ekonomi Pembangunan, 7(1), 46-54. Google Scholar

Anindito, Bagus, \& HARTO, Puji. (2015). Analisis Pengaruh Perputaran Modal Kerja, Struktur Modal, Umur Perusahaan dan Ukuran Perusahaan terhadap Profitabilitas pada Perusahaan yang Tergabung dalam LQ-45 di Bursa Efek Indonesia Tahun 2010-2012. Fakultas Ekonomika dan Bisnis. Google Scholar

Christiawan, Yulius Jogi, \& Tarigan, Josua. (2007). Kepemilikan manajerial: kebijakan hutang, kinerja dan nilai perusahaan. Jurnal Akuntansi Dan Keuangan, 9(1), 1-8. Google Scholar

Cresswell, J. W. (2017). Research Design: Pendekatan Kualitatif, Kuantitatif, dan Mixed (Edisi Ketiga). Yogyakarta: Pustaka Belajar. Google Scholar

Fardiansyah, Ardy, Siagian, Victor, \& Sihombing, Pardomuan. (2018). Determinan Indeks Sektor Pertambangan Di Bei Periode 2012-2017. Prosiding Seminar Nasional Cendekiawan, 847-852. Google Scholar

Gustina, Dhany Lia, \& Wijayanto, Andhy. (2015). Analisis rasio keuangan dalam memprediksi perubahan laba. Management Analysis Journal, 4(2). Google Scholar

Hayati, Tri. (2019). Hak Penguasaan Negara Terhadap Sumber Daya Alam Dan Implikasinya Terhadap Bentuk Pengusahaan Pertambangan. Jurnal Hukum \& Pembangunan, 49(3), 768-787. Google Scholar

Indriyani, Eka. (2017). Pengaruh ukuran perusahaan dan profitabilitas terhadap nilai perusahaan. Akuntabilitas: Jurnal Ilmu Akuntansi, 10(2), 333-348. Google Scholar

Mahalani, Agustina Wahyu, Iksan, Muchammad, Marisa Kurnianingsih, S. H., \& MH, M. Kn. (2016). Proses Pelaksanaan Gelar Perkara (Studi Urgensi Gelar Perkara Dalam Kelancaran Penyelesaian Perkara Pidana). Universitas Muhammadiyah Surakarta. Google Scholar

Nasution, Lenni Masnidar. (2017). Statistik deskriptif. Hikmah, 14(1), 49-55. Google Scholar

Orniati, Yuli. (2009). Laporan keuangan sebagai alat untuk menilai kinerja keuangan. Jurnal Ekonomi Bisnis, 14(3), 206-213. Google Scholar

Prihadi, Toto. (2019). Analisis Laporan Keuangan. Gramedia Pustaka Utama. Google Scholar

Sanjaya, Surya, \& Rizky, Muhammad Fajri. (2018). Analisis Profitabilitas Dalam Menilai Kinerja Keuangan Pada PT. Taspen (Persero) Medan. KITABAH: Jurnal 
Adrian Hartanto, Camila, Ike Rukmana Sari

Akuntansi Dan Keuangan Syariah. Google Scholar

Sidabutar, Elsa Handayani. (2020). Pengaruh Rasio Lancar, Ukuran Perusahaan, Umur Perusahan, dan Leverage Terhadap Profitabilitas. UNIVERSITAS BAKRIE. Google Scholar

Sudrajat, Nandang. (2018). Teori dan Praktik Pertambangan Indonesia. MediaPressindo. Google Scholar

Sugiyono. (2017). Metode Penelitian Kuantitatif. Google Scholar

Umar, Husein. (2002). Evaluasi kinerja perusahaan. Gramedia Pustaka Utama. Google Scholar

\section{Copyright holder:}

Adrian Hartanto, Camila, Ike Rukmana Sari (2021)

\section{First publication right:}

Syntax Literate: Jurnal Ilmiah Indonesia

This article is licensed under:

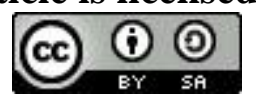

